\title{
Enhancing Knowledge, Beliefs, and Intention to Screen for Prostate Cancer via Different Health Educational Interventions: a Literature Review
}

\author{
Ahmad M Saleh ${ }^{1 *}$, Marjaneh M Fooladi' ${ }^{1}$, Wasileh Petro-Nustas ${ }^{1}$, Ghadeer \\ Dweik $^{2}$, Mohammad H Abuadas ${ }^{3}$
}

\begin{abstract}
Background: Prostate cancer is one of the most common cancers affecting men globally, constituting the sixth leading cause of cancer related death in males, and the eleventh leading cause of death from cancer in all age groups. In Jordan, prostate cancer is the third most common cancer in the male population, accounting for one third $(6.2 \%)$ of cancer related deaths and in 2010 alone, $218(9.4 \%)$ new cases were identified. Objective: To assess the effectiveness of different health education interventions aimed at enhancing knowledge, beliefs and intention to screen for prostate cancer. Materials and Methods: A literature search from January 2000 to April 2015 was conducted using the key words "prostate disease," "educational program," "knowledge," "prostate cancer," "demographic factors and prostate cancer," "knowledge and prostate cancer," "education for patients with prostate cancer," "factors that affect intention to screen," "knowledge, beliefs, and intention to screen for prostate cancer," "impact of prostate educational program on beliefs," and "impact of educational program on intention to screen." Results: Majority of studies reviewed indicated that men had low levels of knowledge regarding prostate cancer, and mild to moderate beliefs with good intention to screen for prostate cancer. Conclusions: Most studies indicated that men's knowledge levels about prostate cancer were poor and they had mild to moderate beliefs and intentions to screen for prostate cancer. Therefore, development of an assessment strategy based on the Health Belief Model seems essential. An effectively designed and implemented educational program can help identify the needs and priorities of the target population.
\end{abstract}

Keywords: Literature review - prostate cancer - knowledge - beliefs and intention to screen - educational programs

Asian Pac J Cancer Prev, 16 (16), 7011-7023

\section{Introduction}

Prostate cancer is defined as the development of cancer in the prostate gland in the male reproductive system (National Cancer Institute, 2015a). Most prostate cancers are slow growing; however, some grow relatively fast (Stewart and Wild, 2014; National Cancer Institute, $2015 \mathrm{~b}$ ). The cancer cells may spread from the prostate to other parts of the body, particularly the bones and lymph nodes (Ruddon, 2007). It may initially cause no symptoms, but in later stages it can cause difficulty urinating, blood in the urine, or pain in the pelvis, back or when urinating (National Cancer Institute, 2015b). Prostate cancer is considered the third most common occurring form of cancer worldwide-about 1.128 million cases, and an estimated 656.000 death in 2012 (Ferlay et al., 2013). It is one of the most common cancers affecting men globally (U.S. Cancer Statistics Working Group, 2009), the sixth leading cause of cancer related death in men, and the eleventh leading cause of death from cancer in all age groups (Lozano et al., 2012). As cited in (Ahmad et al., 2005); "Prostate cancer is the most common malignant neoplasm among men in United State" (Gerard and FrankStromberg, 1998).

In Jordan, prostate cancer is the third most common cancer in the male population, accounting for one third $(6.2 \%)$ of cancer related deaths and in 2010 alone, 218 (9.4\%) new cases were identified (Tarawneh et al., 2010).

Several studies have shown that knowledge, beliefs and intention to screen for prostate cancer among men ages 40 and above are low (Paul et al., 2003; Schulman et al., 2003; Jemal et al., 2007; Weinrich et al., 2007; Chapple et al., 2008; Arafa et al., 2012; Abuadas, 2015). Therefore, researchers conducted a systematic review on different educational interventions to find the most effective ways to improve knowledge, beliefs and intention to screen among men age 40 and over.

This integrative review sought to answer the following research questions: (i) What are the levels of knowledge, beliefs and intention to screen for prostate cancer among

${ }^{1}$ Faculty of Nursing, The University of Jordan, ${ }^{2}$ Faculty of Nursing, Applied Science University, Amman, ${ }^{3}$ Faculty of Nursing, AlGad International Colleges for Applied Medical Sciences, Tabuk, The Kingdom of Saudi Arabia*For correspondence:al_raminy@ yahoo.com 
men over the age of 40 ? (ii) What has been the impact of different educational intervention programs on the level of knowledge, beliefs, and intention to screen for prostate cancer among men over the age of 40 ? (iii) What are the research finding recommendations to enhance prostate cancer knowledge, beliefs and intention to screen for men over the age of 40 ?

\section{Materials and Methods}

Selecting the review topic is the first step in the literature review process followed by identifying relevant publications through searching of the most relevant electronic database after specifying the keywords terms that will be used and the inclusion criteria for articles of interest. The third step in the literature review includes assessing the quality of the studies using critical appraisal and evaluation guides, then we identified the useful and related studies and extracted data by summarizing all selected studies in a literature review matrix after in-depth reading and comprehension for all studies as presented in Table 1.

A suitable data analysis strategy adopted in order to identify the themes of this paper. Researchers accessed CINAHL, MEDLINE and COCHRANE databases for published studies from January, 2000- April, 2015, using the key words prostate cancer, educational program regarding prostate cancer, knowledge and prostate cancer, factors that affect intention to screen, beliefs, and prostate cancer, and impact of educational program on intention to screen of prostate cancer. Furthermore, current issues of periodicals, major nursing and health journals from worldwide resources were manually reviewed.

\section{Inclusion and exclusion criteria}

Research studies (published or unpublished), written in English language and relevance to the topic of knowledge, beliefs, intention to screen for prostate cancer and various educational intervention programs were included. Published work conducted during January, 2000 to April,

Table 1. Methodological Characteristics of the Reviewed Studies

\begin{tabular}{|c|c|c|c|c|}
\hline $\begin{array}{c}\text { Authors } \\
\text { Country/ Year }\end{array}$ & Purpose & Design & Sample & Results \\
\hline \multicolumn{5}{|c|}{ Knowledge, Beliefs, and Intention to Screen regarding Prostate Cancer } \\
\hline \multicolumn{5}{|c|}{ Knowledge of Prostate Cancer among Men } \\
\hline $\begin{array}{l}\text { Agho and Lewis } \\
2001 \\
\text { USA }\end{array}$ & $\begin{array}{l}\text { To investigate the effects } \\
\text { of education, income, } \\
\text { age, and health insurance } \\
\text { coverage on actual and } \\
\text { perceived knowledge of } \\
\text { prostate cancer. }\end{array}$ & $\begin{array}{l}\text { descriptive } \\
\text { relational } \\
\text { study. }\end{array}$ & $\begin{array}{l}\text { nonrandom } \\
\text { sample of } \\
108 \text { African } \\
\text { American men. }\end{array}$ & $\begin{array}{l}\text { Respondents demonstrated a poor knowledge of } \\
\text { prostate cancer and less than } 40 \% \text { reported having } \\
\text { had prostate cancer screening as part of their annual } \\
\text { physical examination. The results of the study also } \\
\text { revealed that (a) there was a moderately strong } \\
\text { correlation between actual and perceived knowledge } \\
\text { of prostate cancer, (b) use of prostate cancer } \\
\text { screening service was positively associated with } \\
\text { actual and perceived knowledge of the disease, (c) } \\
\text { actual knowledge of prostate cancer was negatively } \\
\text { correlated with education, age, and income, and (d) } \\
\text { actual and perceived knowledge of prostate cancer } \\
\text { were both correlated with having health insurance } \\
\text { coverage. }\end{array}$ \\
\hline $\begin{array}{l}\text { Olufisayo and } \\
\text { Sola, } 2010 \\
\text { Nigeria }\end{array}$ & $\begin{array}{l}\text { To assess the knowledge, } \\
\text { awareness, and screening } \\
\text { practices among older men } \\
\text { regarding prostate cancer } \\
\text { in Oyo State, Nigeria. }\end{array}$ & $\begin{array}{c}\text { cross } \\
\text {-sectional } \\
\text { study. }\end{array}$ & $\begin{array}{l}561 \text { adult } \\
\text { males. }\end{array}$ & $\begin{array}{l}\text { Prostate cancer awareness was high [449 }(80.0 \%)] \text {. } \\
\text { The overall mean knowledge of prostate cancer } \\
\text { causation, treatment, and prevention was } 5.8( \pm 3.0) \\
\text { out of a maximum of } 16 \text {. Only } 109(19.4 \%) \text { perceived } \\
\text { themselves at risk of developing prostate cancer, } \\
\text { but only } 4.5 \% \text { have ever been screened. Though } \\
\text { knowledge and risk perception of prostate cancer } \\
\text { were low, a majority of respondents }(81.5 \%) \text { were } \\
\text { willing to be screened for the disease. Community- } \\
\text { based prostate cancer educational interventions and } \\
\text { provision of screening centers are needed for this } \\
\text { group. }\end{array}$ \\
\hline $\begin{array}{l}\text { Ajape et al } \\
2010 \\
\text { Nigeria }\end{array}$ & $\begin{array}{l}\text { To evaluate the awareness } \\
\text { and attitude of the } \\
\text { population to screening for } \\
\text { cancer of the prostate. }\end{array}$ & $\begin{array}{c}\text { Cross-sectional } \\
\text { study }\end{array}$ & $\begin{array}{l}156 \\
\text { respondents. }\end{array}$ & $\begin{array}{l}\text { The result shows that } 78.8 \% \text { have never heard any } \\
\text { information on cancer of the prostate and only } 5.8 \% \\
\text { have heard about PSA. None of the respondents have } \\
\text { ever had PSA test done, } 84 \% \text { of the respondents are } \\
\text { ready to pay for prostate cancer test by PSA assay. }\end{array}$ \\
\hline $\begin{array}{c}\text { Xu et al } \\
2012 \\
\text { USA }\end{array}$ & $\begin{array}{l}\text { To describe prostate cancer } \\
\text { treatment decision making, } \\
\text { focusing on knowledge } \\
\text { and attitudes toward } \\
\text { observation. }\end{array}$ & $\begin{array}{l}\text { Pheno- } \\
\text { meno-logical } \\
\text { study. }\end{array}$ & $\begin{array}{l}\text { Semi structured } \\
\text { in-person } \\
\text { interviews with } \\
21 \text { men (14 } \\
\text { black; } 7 \text { white) } \\
\text { with recently } \\
\text { diagnosed } \\
\text { localized } \\
\text { prostate cancer. }\end{array}$ & $\begin{array}{l}\text { All cancers were detected by prostate-specific antigen } \\
\text { screening; } 14 \text { men had low-risk disease. Nineteen } \\
\text { chose surgery or radiation treatment. The majority } \\
\text { wanted to "get rid of" or "cure" the cancer by } \\
\text { undergoing aggressive therapy, even with awareness } \\
\text { of the potential for significant side effects. Most men } \\
\text { seemed unaware of the uncertainty/controversies that } \\
\text { aggressive treatment may not cure their cancer or } \\
\text { improve their survival. }\end{array}$ \\
\hline
\end{tabular}


Enhancing Knowledge, Beliefs, and Intention to Screen for Prostate Cancer via Different Health Educational Interventions

\begin{tabular}{|c|c|c|c|c|}
\hline $\begin{array}{l}\text { Kroger-Jarvis et } \\
\text { al. } 2014 \\
\text { USA }\end{array}$ & $\begin{array}{l}\text { To evaluate Knowledge of } \\
\text { prostate cancer screening } \\
\text { rural men in Ripley } \\
\text { County, Southeastern } \\
\text { Indiana. }\end{array}$ & Survey. & $\begin{array}{l}\text { A convenience } \\
\text { sample of } 59 \\
\text { men over the } \\
\text { age of } 50 .\end{array}$ & $\begin{array}{l}\text { Although they indicated knowing updated } \\
\text { information regarding prostate cancer screening, } \\
\text { many have not obtained screening. Study findings } \\
\text { point to the need for educational programs designed } \\
\text { to improve prostate cancer screening rates in this } \\
\text { population. }\end{array}$ \\
\hline $\begin{array}{l}\text { Mofolo et al } \\
2015 \\
\text { South } \\
\text { Africa }\end{array}$ & $\begin{array}{l}\text { To assess the knowledge } \\
\text { of prostate cancer among } \\
\text { men attending the urology } \\
\text { outpatient clinic at a } \\
\text { tertiary hospital in South } \\
\text { Africa. }\end{array}$ & $\begin{array}{l}\text { A } \\
\text { cross } \\
\text {-sectional } \\
\text { study. }\end{array}$ & $\begin{array}{l}\text { A total of } 346 \\
\text { males, } 35 \text { years } \\
\text { of age and } \\
\text { older. }\end{array}$ & $\begin{array}{l}\text { More than half }(54.4 \%) \text { of the respondents had not } \\
\text { heard of prostate cancer. The majority of men who } \\
\text { had heard of prostate cancer had a moderate level of } \\
\text { knowledge. }\end{array}$ \\
\hline $\begin{array}{c}\text { Edwards et al } \\
2000 \\
\text { USA }\end{array}$ & $\begin{array}{l}\text { The objectives of this study } \\
\text { were to identify, describe, } \\
\text { classify, and differentiate } \\
\text { African-American men } \\
\text { (AAM) in military settings } \\
\text { according to the frequency } \\
\text { with which they regularly, } \\
\text { infrequently, or did not } \\
\text { screen for prostate cancer } \\
\text { using factors of the Health } \\
\text { Belief Model. }\end{array}$ & $\begin{array}{c}\text { An exploratory } \\
\text { descriptive study. }\end{array}$ & $\begin{array}{l}\text { Participants } \\
\text { in the study } \\
\text { included } \\
147 \text { military } \\
\text { health care } \\
\text { beneficiaries } \\
\text { who were } \\
\text { AAM } 40 \text { years } \\
\text { of age and } \\
\text { older. }\end{array}$ & $\begin{array}{l}\text { The results revealed that } 85 \% \text { of the men reported } \\
\text { having screened for prostate cancer and more } \\
\text { than } 54 \% \text { of them reported screening "annually." } \\
\text { Discriminant analysis statistics revealed that age, } \\
\text { education, and "perceived benefits" of the digital } \\
\text { rectal examination and the prostate-specific antigen } \\
\text { test best differentiated AAM who screened annually } \\
\text { compared with no screeners. Educating AAM on the } \\
\text { benefits and efficacy of the digital rectal examination } \\
\text { and prostate-specific antigen tests may be helpful in } \\
\text { increasing screening practices in this high-risk group. }\end{array}$ \\
\hline $\begin{array}{l}\text { Clarke-Tasker } \\
\text { VA and Wade R } \\
2002 \\
\text { USA }\end{array}$ & $\begin{array}{l}\text { To determine African } \\
\text { American male's } \\
\text { knowledge, attitudes and } \\
\text { perceptions of prostate } \\
\text { cancer and early detection } \\
\text { methods. }\end{array}$ & $\begin{array}{l}\text { An } \\
\text { exploratory } \\
\text { descriptive } \\
\text { study. }\end{array}$ & $\begin{array}{l}\text { Two focus } \\
\text { groups were } \\
\text { conducted } \\
\text { with African- } \\
\text { American men } \\
\text { whose ages } \\
\text { ranged from } \\
\text { 38-80 years. }\end{array}$ & $\begin{array}{l}\text { Men between } 40 \text { and } 50 \text { years of age expressed } \\
\text { concern about possible changes in their sex life } \\
\text { if diagnosed with prostate cancer. Despite having } \\
\text { limited knowledge of prostate cancer they considered } \\
\text { a digital rectal examination to be embarrassing and } \\
\text { uncomfortable. However, they were not opposed to } \\
\text { having the procedure done. }\end{array}$ \\
\hline $\begin{array}{l}\text { Forrester- } \\
\text { Anderson } \\
2005 \\
\text { USA }\end{array}$ & $\begin{array}{l}\text { The purpose of the study } \\
\text { was to explore, using focus } \\
\text { groups, the knowledge, } \\
\text { perceptions, attitudes, } \\
\text { and behavior of African } \\
\text { American men concerning } \\
\text { prostate cancer and } \\
\text { screening for the disease } \\
\text { using the prostate specific } \\
\text { antigen and the digital } \\
\text { rectal examination. }\end{array}$ & $\begin{array}{l}\text { An } \\
\text { exploratory } \\
\text { descriptive } \\
\text { study. }\end{array}$ & $\begin{array}{l}\text { Twelve focus } \\
\text { groups ( } \mathrm{n}=104) \\
\text { were conducted } \\
\text { among African } \\
\text { American men } \\
40 \text { years of age } \\
\text { and older. }\end{array}$ & $\begin{array}{l}\text { The results of the study show various barriers to } \\
\text { screening among the target population, which include } \\
\text { limited knowledge about the disease, lack of access } \\
\text { to screening services, embarrassment and fear of a } \\
\text { positive diagnosis. }\end{array}$ \\
\hline \multicolumn{5}{|c|}{ Intention to screen of Prostate Cancer among Men } \\
\hline $\begin{array}{l}\text { Ronald et al } \\
2000 \\
\text { USA }\end{array}$ & $\begin{array}{l}\text { To identify factors } \\
\text { associated with intention } \\
\text { to be tested for prostate } \\
\text { cancer risk among African- } \\
\text { American men. }\end{array}$ & $\begin{array}{l}\text { Cross } \\
\text {-sectional } \\
\text { design. }\end{array}$ & $\begin{array}{l}548 \text { African- } \\
\text { American } \\
\text { men, who were } \\
\text { patients at the } \\
\text { University } \\
\text { Health Service, } \\
\text { were } 40 \text { to } 70 \\
\text { years of age, } \\
\text { and did not } \\
\text { have a personal } \\
\text { history of } \\
\text { prostate cancer. }\end{array}$ & $\begin{array}{l}\text { Results show that belief in the efficacy of prostate } \\
\text { cancer screening and intention to undergo a prostate } \\
\text { cancer-screening (i.e., digital rectal examination } \\
\text { and prostate-specific antigen testing were positively } \\
\text { associated with intention to be tested for prostate } \\
\text { cancer risk. Past screening, perceived susceptibility, } \\
\text { and beliefs related to early detection might influence } \\
\text { receptivity to genetic testing for prostate cancer risk. }\end{array}$ \\
\hline $\begin{array}{l}\text { Gregory et al } \\
2007 \\
\text { USA }\end{array}$ & $\begin{array}{l}\text { To understand men's } \\
\text { decision-making process } \\
\text { for prostate-specific } \\
\text { antigen (PSA) screening, } \\
\text { especially among elderly } \\
\text { men, and to be more } \\
\text { Knowledgeable for } \\
\text { interventions to modify } \\
\text { screening rates }\end{array}$ & $\begin{array}{l}\text { A } \\
\text { cross } \\
\text {-sectional } \\
\text { design. }\end{array}$ & $\begin{array}{l}\text { Random } \\
\text { sample of } \\
\text { 452 Iowa men } \\
\text { who were free } \\
\text { of prostate } \\
\text { cancer and } \\
\text { aware of PSA }\end{array}$ & $\begin{array}{l}\text { Roughly } 75 \% \text { expressed intent to receive PSA } \\
\text { screening within a year. Attitude, social influence, } \\
\text { and perceived control each contributed significantly } \\
\text { to the explanation of intentions }(\mathrm{p}<0.001) \text {; the model } \\
\text { accounted for } 72 \% \text { of the variability in intention. } \\
\text { Detecting cancer early, obtaining peace of mind, } \\
\text { knowing their PSA value, and false test results were } \\
\text { potential outcomes and each convincingly influenced } \\
\text { attitude. A man's wife, primary care physician, } \\
\text { urologist, family, friends, and people with cancer each } \\
\text { visibly swayed overall perceived social influence. } \\
\text { The impacts of health insurance, transportation, } \\
\text { information, health problems, including PSA in } \\
\text { routine exams, and primary care physicians on } \\
\text { perceived control was less clear. Elderly men were } \\
\text { unaware of the PSA controversy and believed } \\
\text { physicians recommend screening men their age. }\end{array}$ \\
\hline
\end{tabular}


Table 1 (continued). Methodological Characteristics of the Reviewed Studies

\begin{tabular}{|c|c|c|c|c|}
\hline $\begin{array}{l}\text { Odedina et al } \\
2008 \\
\text { USA }\end{array}$ & $\begin{array}{l}\text { To identify personal } \\
\text { factors influencing } \\
\text { African-American men's } \\
\text { participation in prostate } \\
\text { cancer screening. }\end{array}$ & $\begin{array}{l}\text { Two } \\
\text { cross } \\
\text {-sectional } \\
\text { surveys }\end{array}$ & $\begin{array}{l}191 \text { African- } \\
\text { American } \\
\text { men age }>\text { or } \\
=40, \text { married, } \\
\text { urban residents, } \\
\text { full-time } \\
\text { employment } \\
\text { status and } \\
\text { household } \\
\text { income of } \\
\$ 20,000 \\
-\$ 39,000\end{array}$ & $\begin{array}{l}\text { The key determinants of intention to undergo prostate } \\
\text { cancer screening were attitude, perceived behavioral } \\
\text { control, past behavior and perceived susceptibility. } \\
\text { Attitude was the primary determinant of screening } \\
\text { behavior. }\end{array}$ \\
\hline $\begin{array}{l}\text { Smith-McLallen } \\
\text { et al } \\
2009 \\
\text { USA }\end{array}$ & $\begin{array}{l}\text { to examine differences } \\
\text { between Blacks and Whites } \\
\text { in the US in the degree to } \\
\text { which attitudes, perceived } \\
\text { behavioral control } \\
\text { (PBC) and normative } \\
\text { pressure contribute to } \\
\text { predicting intentions to } \\
\text { engage in three cancer } \\
\text { screenings (mammogram, } \\
\text { colonoscopy and PSA test) } \\
\text { and three healthy lifestyle } \\
\text { behaviors (controlling ones } \\
\text { diet to lose weight, eating } \\
\text { fruits and vegetables and } \\
\text { exercising regularly). }\end{array}$ & $\begin{array}{l}\text { Descriptive } \\
\text { design. }\end{array}$ & $\begin{array}{c}\text { African- } \\
\text { American men. }\end{array}$ & $\begin{array}{l}\text { Results indicated that for Blacks intentions to engage } \\
\text { in all behaviors were driven by PBC. Patterns were } \\
\text { more varied for Whites and indicated that normative } \\
\text { pressure was a particularly important determinant } \\
\text { of screening intentions whereas attitudes were most } \\
\text { strongly associated with dieting intentions. Results } \\
\text { suggest that interventions targeting these behaviors } \\
\text { should be tailored by behavior and by ethnicity. }\end{array}$ \\
\hline $\begin{array}{c}\text { Carpenter et al } \\
2009 \\
\text { USA }\end{array}$ & $\begin{array}{l}\text { To examines patients' } \\
\text { usual source of care, } \\
\text { continuity of care, and } \\
\text { mistrust of physicians } \\
\text { and their association with } \\
\text { racial differences in CaP } \\
\text { screening. }\end{array}$ & $\begin{array}{l}\text { Descriptive } \\
\text { correlational } \\
\text { study. }\end{array}$ & $\begin{array}{l}\text { "1,031 African } \\
\text { American and } \\
\text { Caucasian } \\
\text { American men } \\
\text { age } 50 \text { and } \\
\text { over. }\end{array}$ & $\begin{array}{l}\text { Compared with African Americans, Caucasian } \\
\text { Americans exhibited higher physician trust scores and } \\
\text { a greater likelihood of reporting a physician office as } \\
\text { their usual source of care, seeing the same physician } \\
\text { at regular medical encounters, and historically } \\
\text { utilizing any CaP screening. }\end{array}$ \\
\hline $\begin{array}{l}\text { Arras-Boyd et al } \\
2009 \\
\text { USA }\end{array}$ & $\begin{array}{l}\text { To measure knowledge } \\
\text { of benefits and risks of } \\
\text { prostate cancer screening } \\
\text { and compare it with a } \\
\text { comparison group who } \\
\text { did not attend community } \\
\text { education and screening } \\
\text { events. }\end{array}$ & $\begin{array}{l}\text { A } \\
\text { quasi } \\
\text { experimental, } \\
\text { exploratory } \\
\text { study } \\
\text { used } \\
\text { a } \\
\text { pretest/ } \\
\text { post } \\
\text {-test } \\
\text { design } \\
\text { for men }\end{array}$ & $\begin{array}{l}\text { Sampling was } \\
\text { self-selective } \\
\text { and consisted } \\
\text { of } 340 \text { men } \\
\text { who attended } \\
24 \text { education } \\
\text { and screening } \\
\text { events held in } \\
19 \text { locations } \\
\text { over a nine- } \\
\text { month period. }\end{array}$ & $\begin{array}{l}\text { The reasons for higher incidence and mortality rates } \\
\text { from PC in African-American men are complex. } \\
\text { Although screening can detect PC in earlier, } \\
\text { potentially more treatable stages, there remains } \\
\text { controversy over whether or not screening extends } \\
\text { or improves quality of life. Until the issue of routine } \\
\text { screening is resolved, the best strategy is to offer } \\
\text { information about the benefits and risks of screening } \\
\text { and to provide access to screening and treatment for } \\
\text { men without access to healthcare }\end{array}$ \\
\hline $\begin{array}{c}\text { Donna Kenerson } \\
2010 \\
\text { USA }\end{array}$ & $\begin{array}{l}\text { To adapt the Theory of } \\
\text { Planned Behavior (TPB) } \\
\text { to provide a framework for } \\
\text { elucidating Sociocultural } \\
\text { factors associated with } \\
\text { prostate cancer screening } \\
\text { intent among African } \\
\text { American men. }\end{array}$ & $\begin{array}{l}\text { A correlational, } \\
\text { cross-sectional } \\
\text { design was used } \\
\text { to examine the } \\
\text { strength of the } \\
\text { relationship } \\
\text { between } \\
\text { sociocultural } \\
\text { variables and the } \\
\text { intent to participate } \\
\text { in prostate cancer } \\
\text { screening among } \\
\text { African American } \\
\text { men. }\end{array}$ & $\begin{array}{l}\text { Eighty seven } \\
\text { African } \\
\text { American men } \\
40 \text { to } 70 \text { years } \\
\text { of age residing } \\
\text { in Nashville, } \\
\text { Tennessee. }\end{array}$ & $\begin{array}{l}\text { Perceived benefits had a statistically significant } \\
\text { correlation }(\mathrm{r}=0.285, \mathrm{p}=0.018) \text { with prostate cancer } \\
\text { screening intent. } \\
\text { Social influence was found to be statistically } \\
\text { significant associated with intent to screen }(\mathrm{r}=.337 \text {, } \\
\qquad \mathrm{p}=0.005) \text {. } \\
\text { Prostate cancer knowledge was not statistically } \\
\text { significantly associated with prostate cancer screening } \\
\text { intent }(\mathrm{r}=0.132, \mathrm{p}=.279) .\end{array}$ \\
\hline $\begin{array}{l}\text { Anderson } \\
2013 \\
\text { USA }\end{array}$ & $\begin{array}{l}\text { To examines prostate } \\
\text { cancer screening intention } \\
\text { using the health belief } \\
\text { model (HBM). }\end{array}$ & Survey & $\begin{array}{l}392 \text { men white } \\
\text { and black men } \\
\text { aged } 40-70 \\
\text { years old living } \\
\text { in Davidson } \\
\text { County. }\end{array}$ & $\begin{array}{l}\text { First: Age, insurance status, and one income category } \\
\text { had significant effects on prostate cancer screening } \\
\text { intention. Second: this study suggests the addition } \\
\text { of a direct path from the cues to action construct to } \\
\text { preventive health behavior as it functions as a trigger } \\
\text { or catalyst to the behavior. }\end{array}$ \\
\hline
\end{tabular}


Enhancing Knowledge, Beliefs, and Intention to Screen for Prostate Cancer via Different Health Educational Interventions

Table 1 (continued). Methodological Characteristics of the Reviewed Studies

\begin{tabular}{|c|c|c|c|c|}
\hline \multicolumn{5}{|c|}{ Knowledge and Beliefs of Prostate Cancer among Men } \\
\hline $\begin{array}{l}\text { Angelo Dewitt } \\
\text { Moore and } \\
\text { Gerald Boyle } \\
2002 \\
\text { USA }\end{array}$ & $\begin{array}{l}\text { To describe the knowledge } \\
\text { base, perceived threats, } \\
\text { benefits, barriers, and self- } \\
\text { efficacy of prostate cancer } \\
\text { screening. }\end{array}$ & $\begin{array}{l}\text { A descriptive } \\
\text { design. }\end{array}$ & $\begin{array}{l}\text { A convenience } \\
\text { sampling of } \\
234 \text { males in } \\
\text { the National } \\
\text { Capital Area. } \\
\text { Age } 52 \text { and } \\
\text { older from } \\
\text { different sites } \\
\text { (Army, Navy, } \\
\text { and Air Force) } \\
\text { within the } \\
\text { NCA. }\end{array}$ & $\begin{array}{l}\text { The majority }(93 \%) \text { of the participants were very } \\
\text { knowledgeable about prostate cancer and prostate } \\
\text { cancer screening. However, the majority of the } \\
\text { study population appeared to be unsure of when to } \\
\text { start screening for prostate cancer. All concepts of } \\
\text { the HBM (perceived threats, benefits, barriers, and } \\
\text { self-efficacy) appear to affect screening patterns as } \\
\text { indicated by high mean scores on the perception } \\
\text { scales. Two thirds of the participants reported } \\
\text { screening annually for prostate cancer. }\end{array}$ \\
\hline $\begin{array}{l}\text { Blocker et al } \\
2006 . \\
\text { USA }\end{array}$ & $\begin{array}{l}\text { To assess attitudes and } \\
\text { behaviors linked to } \\
\text { prostate cancer prevention } \\
\text { activities that could be } \\
\text { used to develop a culturally } \\
\text { relevant intervention for an } \\
\text { African-American church } \\
\text { based population. }\end{array}$ & $\begin{array}{c}\text { Qualitative, } \\
\text { phenomenological } \\
\text { design }\end{array}$ & $\begin{array}{l}\text { The ages of the } \\
\text { participants } \\
\text { ranged from } \\
34-68 \text { years } \\
\text { old. Fourteen } \\
\text { African- } \\
\text { American men } \\
\text { and } 15 \text { African- } \\
\text { American } \\
\text { women } \\
\text { participated in } \\
\text { the four focus } \\
\text { groups. }\end{array}$ & $\begin{array}{l}\text { Three primary themes emerged from the focus group } \\
\text { discussions: 1) culturally and gender-influenced } \\
\text { beliefs and barriers about cancer prevention and } \\
\text { screening; 2) barriers related to the healthcare system; } \\
\text { and 3) religious influences, including the importance } \\
\text { of spiritual beliefs and church support. }\end{array}$ \\
\hline $\begin{array}{l}\text { McFall et al } \\
2006 . \\
\text { USA }\end{array}$ & $\begin{array}{l}\text { To compare beliefs } \\
\text { across three racial/ethnic } \\
\text { categories concerning } \\
\text { prostate cancer etiology } \\
\text { and risk, screening } \\
\text { routines, and shared } \\
\text { decision-making. }\end{array}$ & $\begin{array}{l}\text { Exploratory, } \\
\text { descriptive study. }\end{array}$ & $\begin{array}{l}90 \text { African } \\
\text { American } \\
\text { participants. }\end{array}$ & $\begin{array}{l}\text { "Few were aware that prostate cancer is asympto- } \\
\text { matic in early stages. Confidence in knowledge of } \\
\text { screening routines was high, but included misconcep- } \\
\text { tions supporting initiation of screening at earlier ages. } \\
\text { Females encouraged screening of male relatives to } \\
\text { protect their health. } \\
\text { While racial/ethnic groups had similar views and } \\
\text { knowledge about screening, African Americans } \\
\text { wanted to address the threat of prostate cancer in their } \\
\text { communities. Hispanics had awakening awareness } \\
\text { of the health risks of prostate cancer. Non-Hispanic } \\
\text { Whites were aware of the health threat of prostate } \\
\text { cancer. Participants were not aware of controversy } \\
\text { about screening. }\end{array}$ \\
\hline $\begin{array}{c}\text { Chanty et al } \\
2006 \\
\text { USA }\end{array}$ & $\begin{array}{l}\text { To examines the } \\
\text { knowledge, attitudes, } \\
\text { and beliefs of African- } \\
\text { American men and their } \\
\text { female significant others } \\
\text { regarding prostate cancer } \\
\text { screening. }\end{array}$ & $\begin{array}{c}\text { Phenomenological } \\
\text { design. }\end{array}$ & $\begin{array}{c}\text { A total of } 18 \\
\text { men ages }>40 \\
\text { years and } 14 \\
\text { women ages } \\
>30 \text { years } \\
\text { participated in } \\
\text { the focus group } \\
\text { discussions. }\end{array}$ & $\begin{array}{l}\text { The groups expressed multiple apprehensions toward } \\
\text { prostate cancer screening, including feelings of } \\
\text { vulnerability, compromised manhood, and discomfort. } \\
\text { They also shared motivators for screening, including } \\
\text { female significant others, physician recommendation, } \\
\text { early education, and church influence. }\end{array}$ \\
\hline $\begin{array}{l}\text { Levi Rosse et al } \\
2007 \\
\text { USA }\end{array}$ & $\begin{array}{l}\text { To evaluate the usefulness } \\
\text { of the theory of reasoned } \\
\text { action as a model to } \\
\text { explain and predict prostate } \\
\text { cancer information-seeking } \\
\text { behavior by African } \\
\text { American men. }\end{array}$ & $\begin{array}{l}\text { A } \\
\text { descriptive, } \\
\text { repeated } \\
\text { cross } \\
\text {-sectional } \\
\text { research } \\
\text { design }\end{array}$ & $\begin{array}{l}\text { Fifty-two Afri- } \\
\text { can American } \\
\text { men, } 35 \text { years } \\
\text { of age and } \\
\text { older, who have } \\
\text { never been } \\
\text { diagnosed with } \\
\text { prostate cancer }\end{array}$ & $\begin{array}{l}\text { Positive behavioral beliefs for obtaining prostate } \\
\text { cancer information from physicians included increas- } \\
\text { ing awareness of and obtaining accurate information } \\
\text { about the disease, early detection and screening, and } \\
\text { treatment. Negative beliefs included fear, distrust, and } \\
\text { inconvenience. Significant others, peers, siblings, and } \\
\text { religious leaders were identified as individuals who } \\
\text { could influence this behavior. These findings provide } \\
\text { additional insight into ways to reach and intervene } \\
\text { with African American men to influence this impor- } \\
\text { tant cancer control activity. }\end{array}$ \\
\hline
\end{tabular}


Table 1 (continued). Methodological Characteristics of the Reviewed Studies

\begin{tabular}{|c|c|c|c|c|}
\hline $\begin{array}{l}\text { Elenir Pereira de } \\
\text { Paiva, et al } \\
2009 \\
\text { Brazil }\end{array}$ & $\begin{array}{l}\text { "To analyze knowledge } \\
\text { attitudes and practices } \\
\text { towards prostate cancer in } \\
\text { men aged from } 50 \\
\text { and } 80 \text { ascribed to a unit of } \\
\text { the Family Health Program } \\
\text { in Juiz de Fora municipal } \\
\text { district - MG. }\end{array}$ & $\begin{array}{l}\text { A } \\
\text { sectional } \\
\text { study. }\end{array}$ & $\begin{array}{l}\text { a simple } \\
\text { random sample } \\
\text { of } 160 \text { men of } \\
457 \text { men of an } \\
\text { ascribed area } \\
\text { to a PSF of } \\
\text { Juiz de Fora } \\
\text { County, MG. }\end{array}$ & $\begin{array}{l}\text { The majority of participants had knowledge about } \\
\text { detection of prostate cancer. Great number of them } \\
\text { had attitudes and engaged in adequate practice for the } \\
\text { detection of prostate cancer. }\end{array}$ \\
\hline $\begin{array}{c}\text { Mostafa A } \\
\text { Arafa, Danny } \\
\text { Rabah and Iman } \\
\text { Wahdan } \\
2012 \\
\text { Saudi } \\
\text { Arabia } \\
\text { and Jordan }\end{array}$ & $\begin{array}{l}\text { Exploring the knowledge } \\
\text { and beliefs of men aged } \\
\text { forty years and over } \\
\text { towards prostate can- } \\
\text { cer screening and early } \\
\text { detection in three Arab } \\
\text { countries. }\end{array}$ & $\begin{array}{l}\text { A } \\
\text { comparative } \\
\text { cross } \\
\text { sectional study. }\end{array}$ & 400 subjects. & $\begin{array}{l}\text { They had poor knowledge and fair attitude towards } \\
\text { prostate cancer screening behavior, where the mean } \\
\text { total knowledge score was } 10.25 \pm 2.5,10.76 \pm 3.39 \text { and } \\
11.24 \pm 3.39 \text { whereas the mean total attitude score was } \\
18.3 \pm 4.08,20.68 \pm 6.4 \text { and } 17.96 \pm 5.3 \text { for Saudi Arabia, } \\
\text { Egypt and Jordan respectively. }\end{array}$ \\
\hline $\begin{array}{l}\text { H. Nakandi et al } \\
2013 \\
\text { Kampala }\end{array}$ & $\begin{array}{l}\text { To assess the current } \\
\text { knowledge, attitudes and } \\
\text { practices of adult Ugandan } \\
\text { men regarding prostate } \\
\text { cancer. }\end{array}$ & $\begin{array}{l}\text { A } \\
\text { descriptive } \\
\text { cross- } \\
\text { sectional } \\
\text { study. }\end{array}$ & $\begin{array}{l}545 \text { adult men } \\
\text { aged } 18-71 \\
\text { years, residing } \\
\text { in Kampala, } \\
\text { the capital of } \\
\text { Uganda. }\end{array}$ & $\begin{array}{l}\text { There was generally poor knowledge and several } \\
\text { misconceptions regarding prostate cancer and } \\
\text { screening in the study population. }\end{array}$ \\
\hline $\begin{array}{l}\text { Fariba et al } \\
2014 \\
\text { Iran }\end{array}$ & $\begin{array}{l}\text { To investigate the level } \\
\text { of knowledge and health } \\
\text { beliefs about prostate } \\
\text { cancer screening among } \\
\text { retired men. }\end{array}$ & $\begin{array}{c}\text { Descriptive } \\
\text { study. }\end{array}$ & $\begin{array}{l}180 \text { men } \\
\text { aged 50-70 } \\
\text { years who } \\
\text { were retired } \\
\text { from Shiraz } \\
\text { Education } \\
\text { Department. }\end{array}$ & $\begin{array}{l}\text { Findings showed that } 95.6 \% \text { and } 85.6 \% \text { of the } \\
\text { interviewees had no experience of digital rectal } \\
\text { examination (DRE) and prostatic-specific-antigen } \\
\text { (PSA) testing for prostate cancer screening, } \\
\text { respectively. } 86.1 \% \text { of men had no knowledge about } \\
\text { such screening. } 74.4 \% \text { and } 90.5 \% \text { of them had good } \\
\text { health motivation and perceived benefits scores, } \\
\text { respectively. } 81.6 \% \text { of them revealed intermediate } \\
\text { scores for perceived barriers. Moreover, } 32.7 \% \text { and } \\
7.2 \% \text { of the subjects reported good severity and } \\
\text { susceptibility scores, respectively. }\end{array}$ \\
\hline \multicolumn{5}{|c|}{ Knowledge, Beliefs and Intention to Screen of Prostate Cancer among Men } \\
\hline $\begin{array}{l}\text { Wanyagah et al } \\
2013 \\
\text { Kenya }\end{array}$ & $\begin{array}{l}\text { To evaluate the awareness } \\
\text { and knowledge levels; } \\
\text { perception of prostate } \\
\text { cancer self-vulnerability } \\
\text { and uptake of prostate } \\
\text { cancer screening in Nairobi } \\
\text { County. }\end{array}$ & $\begin{array}{l}\text { Cross } \\
\text {-sectional } \\
\text { descriptive } \\
\text { study. }\end{array}$ & $\begin{array}{l}\text { Men }(n=581) \\
\text { of age } 30-73 \\
\text { years. }\end{array}$ & $\begin{array}{l}\text { The results of this study demonstrate higher } \\
\text { awareness but low knowledge levels on prostate } \\
\text { cancer that are accompanied by low perceptions on } \\
\text { self-vulnerability to the cancer, low uptake of prostate } \\
\text { cancer screening that parallel poor knowledge and } \\
\text { perceptions on prostate cancer self-vulnerability and } \\
\text { uptake of screening. Thus, public health intervention } \\
\text { targeting information dissemination on prostate } \\
\text { cancer; behavioral change on risk perceptions; and } \\
\text { uptake of early screening of prostate cancer can halt } \\
\text { the increasing burden of the disease. }\end{array}$ \\
\hline $\begin{array}{l}\text { Abuadas } \\
2015 \\
\text { Jordan }\end{array}$ & $\begin{array}{l}\text { To investigate the level } \\
\text { of knowledge and health } \\
\text { beliefs and intention to } \\
\text { screen about prostate } \\
\text { cancer among older } \\
\text { Jordanian men in Amman. }\end{array}$ & $\begin{array}{l}\text { Descriptive } \\
\text { Correlational } \\
\text { study. }\end{array}$ & $\begin{array}{c}\text { Jordanian older } \\
\text { adults, aged } 40 \\
\text { years and over, } \\
\text { who visited a } \\
\text { comprehensive } \\
\text { health care } \\
\text { center within } \\
\text { a ministry of } \\
\text { health. }\end{array}$ & $\begin{array}{l}\text { The level of Knowledge, Beliefs, and intention to } \\
\text { screen among Jordanian older adult men are low, } \\
\text { which indicate the important to provide health } \\
\text { education program to them }\end{array}$ \\
\hline \multicolumn{5}{|c|}{ The impact of educational intervention programs on the level of knowledge, beliefs, intention to screen for prostate cancer } \\
\hline \multicolumn{5}{|c|}{ The Impact of Different Educational Programs on the Level of Knowledge } \\
\hline $\begin{array}{l}\text { Taylor et al } \\
2001 \\
\text { USA }\end{array}$ & $\begin{array}{l}\text { To develop and evaluate } \\
\text { health education materials } \\
\text { designed to help African } \\
\text { American men make an } \\
\text { informed decision about } \\
\text { prostate cancer screening. }\end{array}$ & $\begin{array}{l}\text { Eight } \\
\text { focus } \\
\text { groups, } \\
\text { Pheno } \\
\text {-menological } \\
\text { study. }\end{array}$ & $\begin{array}{l}\text { Eight focus } \\
\text { groups with } 44 \\
\text { members of the } \\
\text { Prince Hall } \\
\text { Masons. }\end{array}$ & $\begin{array}{l}\text { Participants demonstrated a high level of awareness } \\
\text { of the availability of prostate cancer screening, a } \\
\text { low knowledge of the screening controversy, and } \\
\text { a desire for detailed epidemiologic information } \\
\text { and information about the benefits and limitations } \\
\text { of screening. The preferred forms of educational } \\
\text { materials were video and print-based materials. }\end{array}$ \\
\hline $\begin{array}{l}\text { Frosch et al } \\
2003 \\
\text { USA }\end{array}$ & $\begin{array}{l}\text { To compare the clini- } \\
\text { cal effectiveness of an } \\
\text { internet-based decision aid } \\
\text { with a video for educating } \\
\text { men about issues relevant } \\
\text { to PSA screening. }\end{array}$ & $\begin{array}{l}\text { A } \\
\text { pre- } \\
\text { and } \\
\text { posttest } \\
\text { 2-group } \\
\text { design. }\end{array}$ & $\begin{array}{l}226 \text { men, aged } \\
50 \text { years or } \\
\text { older. }\end{array}$ & $\begin{array}{l}\text { Participants in the video group showed significantly } \\
\text { greater increases in prostate specific antigen knowl- } \\
\text { edge and were more likely to decline the PSA test } \\
\text { than individuals assigned to the internet group. }\end{array}$ \\
\hline
\end{tabular}


Table 1 (continued). Methodological Characteristics of the Reviewed Studies

\begin{tabular}{|c|c|c|c|c|}
\hline $\begin{array}{l}\text { Wilkinson et al } \\
2003\end{array}$ & $\begin{array}{l}\text { To determine whether } \\
\text { an education program } \\
\text { on prostate cancer could } \\
\text { improve awareness and } \\
\text { knowledge among African- } \\
\text { American men. }\end{array}$ & $\begin{array}{l}\text { A } \\
\text { pre- } \\
\text { and } \\
\text { posttest } \\
\text { 1-group } \\
\text { design. }\end{array}$ & $\begin{array}{l}900 \text { African- } \\
\text { American } \\
\text { adults attending } \\
\text { prostate cancer } \\
\text { education } \\
\text { seminars in } \\
\text { community } \\
\text { settings } \\
\text { throughout } \\
\text { Illinois } \\
\text { between March } \\
1998 \text { and } \\
\text { January 2001. }\end{array}$ & $\begin{array}{l}\text { The mean survey score improved from } 26.0 \% \text { before } \\
\text { the seminar to } 73.3 \% \text { after it }(\mathrm{P}<0.0001) \text {. Every } \\
\text { multiple-choice question was answered correctly } \\
\text { more often after the seminar than before it. Increas- } \\
\text { ing levels of education and income were associated } \\
\text { with higher before and after scores }(\mathrm{P}<0.001) \text {. Men } \\
\text { achieved a significantly greater score improvement } \\
\text { (mean } 48.1 \% \text { ) compared with women (mean } 41.1 \% \text {; } \\
\qquad \mathrm{P}=0.006 \text { ). }\end{array}$ \\
\hline $\begin{array}{l}\text { Ruthman and } \\
\text { Ferrans } \\
2003 \\
\text { USA }\end{array}$ & $\begin{array}{l}\text { To test the effectiveness of } \\
\text { a video to teach patients } \\
\text { about prostate cancer } \\
\text { screening and treatment in } \\
\text { a clinic setting. }\end{array}$ & $\begin{array}{l}\text { A } \\
\text { staged, } \\
\text { two-group, } \\
\text { pretest- } \\
\text { posttest } \\
\text { quasi } \\
\text {-experimental } \\
\text { design } \\
\text { was used. }\end{array}$ & $\begin{array}{c}\text { Subjects were } \\
\text { men }(\mathrm{n}=104) \\
\text { who. Inclusion } \\
\text { criteria were } \\
\text { the following: } \\
\text { male, ages } 50 \\
\text { to } 80 \text { years, } \\
\text { scheduled } \\
\text { for a routine } \\
\text { appointment, } \\
\text { no known } \\
\text { prostate cancer, } \\
\text { and no history } \\
\text { of PSA greater } \\
\text { than } 4.0 \mathrm{ng} / \mathrm{ml} .\end{array}$ & $\begin{array}{l}\text { Knowledge increased significantly from pretest } \\
\text { to posttest for the experimental group, but not for } \\
\text { the control group }(\mathrm{p}<.001) \text {. More patients in the } \\
\text { experimental group changed their preference for } \\
\text { prostate-specific antigen (PSA) screening ( } 31 \% \\
\text { experimental vs. } 2 \% \text { control, } \mathrm{p}=.002)\end{array}$ \\
\hline $\begin{array}{l}\text { Gattellari and } \\
\text { Ward } \\
2005 \\
\text { Australia }\end{array}$ & $\begin{array}{l}\text { To facilitate informed } \\
\text { decisions about prostate } \\
\text { cancer screening. }\end{array}$ & $\begin{array}{l}\text { Randomised } \\
\text { controlled } \\
\text { trials. }\end{array}$ & $\begin{array}{l}421 \text { men } \\
\text { recruited from } \\
\text { the community. }\end{array}$ & $\begin{array}{l}\text { Men in all three groups demonstrated significant } \\
\text { increases in knowledge scores from pre to post-test. } \\
\text { Men require detailed information about the pros and } \\
\text { cons of PSA screening in order to make an informed } \\
\text { decision. }\end{array}$ \\
\hline $\begin{array}{l}\text { Taylor } \\
2006 \\
\text { USA }\end{array}$ & $\begin{array}{l}\text { To determine the effect } \\
\text { of the interventions on } \\
\text { knowledge, decisional } \\
\text { conflict, satisfaction with } \\
\text { the screening decision, and } \\
\text { self-reported screening. }\end{array}$ & $\begin{array}{l}\text { Randomized } \\
\text { trial. }\end{array}$ & $\begin{array}{l}238 \text { African } \\
\text { American men. }\end{array}$ & $\begin{array}{l}\text { The booklet and video resulted in a significant } \\
\text { improvement in knowledge and a reduction in } \\
\text { decisional conflict about prostate cancer screening, } \\
\text { relative to the wait list control. Satisfaction with } \\
\text { the screening decision was not affected by the } \\
\text { interventions. Self-reported screening rates increased } \\
\text { between the baseline and the 1-year assessment. }\end{array}$ \\
\hline \multicolumn{5}{|c|}{ The Impact of Different Educational Programs on the Level of Knowledge and Beliefs } \\
\hline $\begin{array}{l}\text { Baqar } \\
2008 \\
\text { USA }\end{array}$ & $\begin{array}{l}\text { "To evaluate an educational } \\
\text { intervention program } \\
\text { with a culturally tailored } \\
\text { curriculum based on a peer } \\
\text { education model. }\end{array}$ & $\begin{array}{c}\text { a quasi- } \\
\text { experimental } \\
\text { delayed control } \\
\text { (crossover) design }\end{array}$ & $\begin{array}{l}\text { A convenience } \\
\text { sample of } \\
430 \text { African } \\
\text { American male } \\
\text { volunteers } \\
\text { (ages } 40-70 \text { ) } \\
\text { was enrolled } \\
\text { through the } \\
\text { churches }\end{array}$ & $\begin{array}{l}\text { Within each group, knowledge, perceived threat, and } \\
\text { screening prevalence all increased significantly. }\end{array}$ \\
\hline $\begin{array}{l}\text { Caryn } \\
2009 \\
\text { USA }\end{array}$ & $\begin{array}{l}\text { Examine the efficacy } \\
\text { of a brief digital video } \\
\text { intervention on levels } \\
\text { of know ledge and } \\
\text { perceived individual risk of } \\
\text { developing prostate cancer } \\
\text { for men of average risk. }\end{array}$ & $\begin{array}{l}\text { Quazi } \\
\text { Experimental } \\
\text { design, Pre- test/ } \\
\text { post- test. }\end{array}$ & $\begin{array}{l}123 \text { Caucasian } \\
\text { men, ages } 45 \text { to } \\
75 \text { years. }\end{array}$ & $\begin{array}{l}\text { Men scored significantly higher on a knowledge } \\
\text { questionnaire and were significantly more likely to } \\
\text { rate their personal risk of developing prostate cancer } \\
\text { correctly after watching the video. }\end{array}$ \\
\hline $\begin{array}{l}\text { Capık and } \\
\text { Gozum } \\
2012 \\
\text { Turkey }\end{array}$ & $\begin{array}{l}\text { To investigate the effect of } \\
\text { web-assisted education and } \\
\text { reminders on health belief, } \\
\text { level of knowledge and } \\
\text { early diagnosis behaviors } \\
\text { regarding prostate cancer } \\
\text { screening. }\end{array}$ & $\begin{array}{l}\text { A single group lon- } \\
\text { gitudinal design }\end{array}$ & $\begin{array}{l}\text { A total of } 1744 \\
\text { persons above } \\
40 \text { years of age } \\
\text { who worked } \\
\text { in two public } \\
\text { institutions. }\end{array}$ & $\begin{array}{l}\text { "participants' prostate examination rate increased } \\
\text { from } 9.3 \% \text { to } 19.1 \% \text { and } \\
\text { PSA measurement rate increased from } 6.7 \% \text { to } \\
\text { 31.4\%. The interventions raised the susceptibility } \\
\text { perception on prostate cancer and prostate cancer } \\
\text { screening while decreasing the barrier perception }(\mathrm{P}< \\
\text { 0.05). No change was observed in other health belief } \\
\text { components and the level of knowledge. }\end{array}$ \\
\hline
\end{tabular}




\begin{tabular}{|c|c|c|c|c|}
\hline $\begin{array}{l}\text { Nnodimele et al } \\
2010 \\
\text { Nigeria }\end{array}$ & $\begin{array}{l}\text { To measure the level } \\
\text { of awareness, specific } \\
\text { knowledge, perception } \\
\text { and screening behavior } \\
\text { of prostate cancer among } \\
\text { males. }\end{array}$ & $\begin{array}{l}\text { A cross-sectional } \\
\text { design }\end{array}$ & $\begin{array}{l}\text { "398 men aged } \\
\text { between } 30 \\
\text { and } 72 \text { years } \\
\text { were enrolled } \\
\text { for the study } \\
\text { by systematic } \\
\text { random } \\
\text { selection. }\end{array}$ & $\begin{array}{l}\text { The findings suggest that level of awareness about } \\
\text { prostate cancer among men in this study was low } \\
\text { while their level of perception was just above } \\
\text { average and screening behavior was very low. Again, } \\
\text { perception variables positively and significantly } \\
\text { correlated with screening behaviour among the } \\
\text { participants. }\end{array}$ \\
\hline $\begin{array}{l}\text { Bettina et al } \\
2010 \\
\text { UK }\end{array}$ & $\begin{array}{l}\text { "To: (1) increase knowl- } \\
\text { edge about prostate cancer } \\
\text { (CaP) screening; and (2) } \\
\text { promote self-efficacy to } \\
\text { participate in the informed } \\
\text { decision-making (IDM) } \\
\text { process. }\end{array}$ & $\begin{array}{c}\text { A quasi } \\
\text { experimental, } \\
\text { pretest-posttest } \\
\text { design was used to } \\
\text { assess the impact } \\
\text { of the intervention. }\end{array}$ & $\begin{array}{l}73 \text { convenience } \\
\text { sample of men } \\
\text { were recruited } \\
\text { through seven } \\
\text { different } \\
\text { churches.1) } \\
\text { self-identified } \\
\text { as African- } \\
\text { American; } 2 \text { ) } \\
\text { between the } \\
\text { ages of } 40 \text { and } \\
70 \text {; and } 3 \text { ) had } \\
\text { never been } \\
\text { diagnosed with } \\
\text { prostate cancer. }\end{array}$ & $\begin{array}{l}\text { The main outcome measures were change in } \\
\text { knowledge and self-efficacy post intervention. Cancer } \\
\text { prostate knowledge }(\mathrm{p}<0.0001) \text { and self-efficacy } \\
(\mathrm{p}=0.025) \text { significantly increased. }\end{array}$ \\
\hline \multicolumn{5}{|c|}{ The Impact of Different Educational Programs on the Level of Knowledge and Intention to Screen } \\
\hline $\begin{array}{l}\text { Melissa Partin } \\
\text { et al } \\
2004 \\
\text { USA }\end{array}$ & $\begin{array}{l}\text { "To assess the effect of } \\
\text { video and pamphlet inter- } \\
\text { ventions } \\
\text { on patient prostate } \\
\text { cancer (CaP) screening } \\
\text { knowledge, } \\
\text { Decision-making } \\
\text { participation, preferences, } \\
\text { and behaviors. }\end{array}$ & $\begin{array}{l}\text { Randomized, } \\
\text { controlled trial. }\end{array}$ & $\begin{array}{l}1152 \text { male } \\
\text { veterans age } 50 \\
\text { and older were } \\
\text { randomized } \\
\text { and } 893 \\
\text { completed } \\
\text { follow-up. }\end{array}$ & $\begin{array}{l}\text { The results suggest that both interventions evaluated } \\
\text { modestly enhance patient } \mathrm{CaP} \text { screening knowledge } \\
\text { and self-reported participation in decision making, } \\
\text { and decrease interest in screening relative to controls. }\end{array}$ \\
\hline $\begin{array}{l}\text { Flora et al } \\
2013 \\
\text { USA }\end{array}$ & $\begin{array}{l}\text { The main purpose of } \\
\text { the study is to test the } \\
\text { feasibility and acceptability } \\
\text { of a culturally appropriate } \\
\text { PCa education intervention } \\
\text { among low-income African } \\
\text { Americans. }\end{array}$ & $\begin{array}{l}\text { "A single-group } \\
\text { non-randomized } \\
\quad \text { education } \\
\text { intervention study }\end{array}$ & $\begin{array}{l}539 \text { low- } \\
\text { income African } \\
\text { American men } \\
\text { aged } 42 \text { years } \\
\text { and older, who } \\
\text { did not screen } \\
\text { for PCa in the } \\
\text { past } 12 \text { months. }\end{array}$ & $\begin{array}{l}\text { Mean knowledge score of } 21 \text { points increased from } \\
13.27+-3.51 \text { to } 14.95+-4.14 \text { ( }<<.001 \text { ), and prostate- } \\
\text { specific antigen screening from } 22.1 \% \text { to } 62.8 \% \text {. }\end{array}$ \\
\hline $\begin{array}{l}\text { Folakemi et al } \\
2014 \\
\text { USA }\end{array}$ & $\begin{array}{l}\text { To explore the impact of } \\
\text { the W.O.R.D video on the } \\
\text { following variables: } \mathrm{CaP} \\
\text { knowledge, CaP screening } \\
\text { intention, and decisional } \\
\text { conflict. }\end{array}$ & $\begin{array}{l}\text { A quasi } \\
\text { experimental, a } \\
\text { pre-, post-test } \\
\text { research design }\end{array}$ & $\begin{array}{l}142 \text { black } \\
\text { men, age } 35 \\
\text { and above, } \\
\text { regardless of } \\
\text { CaP history. } \\
\text { Men who were } \\
\text { not black men } \\
\text { of African } \\
\text { ancestry and } \\
\text { who were } \\
\text { unable to speak } \\
\text { English were } \\
\text { excluded from } \\
\text { participating in } \\
\text { the study. }\end{array}$ & $\begin{array}{l}\text { The mean pre-test knowledge score was } 63.6 \% \text {, and } \\
\text { the mean post-test knowledge score after intervention } \\
\text { exposure was } 74.0 \% \text {., while the baseline score of } \\
\text { participants on the intention scale was high, the } \\
\text { intervention exposure slightly increased the mean } \\
\text { score of participants on this scale. The number } \\
\text { of uncertainty factors perceived by participants } \\
\text { decreased slightly after watching the W.O.R.D video. }\end{array}$ \\
\hline
\end{tabular}

2015, using quantitative, qualitative, mixed methods and systematic reviews were included. Prostate cancer studies from hospitals, clinics, and community surveys for men over the age 40 were also considered for this review. All the studies that did not match the inclusion criteria were excluded.

\section{Results}

As part of the methodological analysis researchers examined study characteristics for country of origin, purpose, sample, study design, theoretical framework and the applied instrument. A total of 123 full-text articles were retrieved (Figure 1), titles were screened for relevance and abstracts were read carefully. All the studies that did not match the inclusion criteria were excluded. After careful review of the articles contents and relevance to the objectives of this study, 42 articles were selected according to the inclusion criteria and others that did not match were omitted.

After screening 123 published research studies on the 
Identification

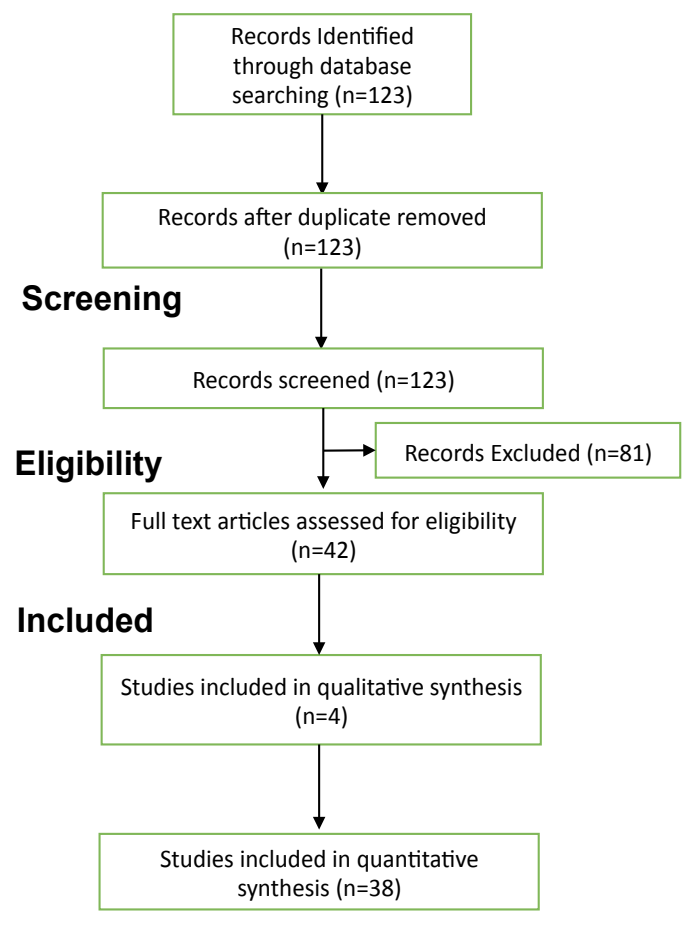

Fig 1 | Search strategy to identify studies regarding Knowledge, Beliefs, and Intention to Screen in addition to different health educational interventions for prostate cancer.

Figure 1. Search Strategy to Identify Studies Regarding Knowledge, Beliefs, and Intention to Screen in Addition to Different Health Educational Interventions for Prostate Cancer

knowledge, beliefs and intention to screen for prostate cancer, we chose 42 articles for our systematic literature review and tabulated our findings from the selected empirical studies that included men between the ages of 18-80 years, used various instruments with established validity and reliability scales, questionnaires and educational interventions to enhance knowledge, beliefs, and intention to screen for prostate cancer.

Except for four qualitative study, others were quantitative research and mainly published in cancer related journals. Most of the selected studies used descriptive, interventional and some correlational methods with quasi experimental and few were randomized clinical trials (RCTs).

Intention to screen for prostate cancer has been investigated in different ways and with different study designs. All studies aimed at several issues related to significance of knowledge and beliefs on intention to screen for prostate cancer, impact of different health educational Interventions on enhancing men's knowledge and beliefs and its affect on the intention to screen for prostate cancer was also addressed in the studies. Some of the studies aimed to assess the knowledge, awareness, and screening practices among older men regarding prostate cancer, other studies investigated the relationship between the Impact of different educational programs on the level of knowledge, beliefs and on intention to screen for prostate cancer. Participants of the majority of the studies were older adults men, aged 40 years and over. The selected empirical studies included various valid and reliable scales and questionnaires which measured several issues related to intention to screen for prostate cancer.

\section{Discussion}

Knowledge, beliefs, and intention to screen regarding prostate cancer

Reviewed findings from selected literature on the overall concepts of knowledge, beliefs, and intension to screen for prostate cancer, identified men ages 40 and above with limited knowledge, beliefs and intention to screen for prostate cancer. In Nigeria, a study by Ajape et al., (2010) to evaluate the awareness and attitude of the population regarding screening for cancer of the prostate, the result shows that $78.8 \%$ have never heard any information on cancer of the prostate and only $5.8 \%$ have heard about PSA, this result was congruent with another study by (Mofolo et al., 2015) in south Africa which revealed that more than half $(54.4 \%)$ of the respondents had not heard of prostate cancer; the majority of men who had heard of prostate cancer had a moderate level of knowledge.

Studies in United States indicated that attitude patterns changed for all cancer screening modalities based on age, gender, racial and ethnic backgrounds. However, "recommended screening intervals" was consistently lower among the less educated men, which attributed to less knowledge about prostate cancer (Breen et al., 2001; Paiva et al., 2009; Kroger-Jarvis, 2014). Similarly, researchers in the United States, found that exposure to information on prostate cancer positively predicted participation in cancer screening (Nivens et al., 2001).

Agho and Lewis (2001) reported that among 108 African-American men, there was a statistically significant relationship between perceived knowledge about prostate cancer and participation in screening $(r=0.55, \mathrm{p} 0.001)$.

In addition to knowledge impact on intention to screen prostate cancer, health beliefs are important factors. Myers et al. (2000) found that among 548 African-American men ages $40-70$ years there was a positive relationship in their health beliefs about prostate cancer screening, screening rates and treatment.

Using factors of the Health Belief Model, a study was conducted to identify, describe, classify, and differentiate African-American men (AAM) in military settings according to the frequency with which they regularly, infrequently, or did not screen for prostate cancer, the discriminant analysis statistics revealed that age, education, and "perceived benefits" of the digital rectal examination and the prostate-specific antigen test best differentiated AAM who screened annually compared with no screeners. Educating AAM on the benefits and efficacy of the digital rectal examination and prostate-specific antigen tests may be helpful in increasing screening practices in this high-risk group (Edwards et al., 2000).

Health belief model was also used to examine prostate cancer screening intention; Age, insurance status, and one income category had significant effects on prostate cancer screening intention (Moore and Boyle, 2003; Anderson, 
2013).

In United States, a study was conducted to explore the knowledge, perceptions, attitudes, and behavior of African American men concerning prostate cancer and screening for the disease using the prostate specific antigen and the digital rectal examination showed various barriers to screening among the target population, which include limited knowledge about the disease, lack of access to screening services, embarrassment and fear of a positive diagnosis (Forrester-Anderson, 2005).

The same barriers were founded by a study conducted in USA, entitle "What we thought we knew: African American males' perceptions of prostate cancer and screening methods" to determine African American male's knowledge, attitudes and perceptions of prostate cancer and early detection methods, findings revealed that men between 40 and 50 years of age have limited knowledge of prostate cancer and they belief that the digital rectal examination to be embarrassing and uncomfortable procedure. However, they were not opposed to having the procedure done (Clarke-Tasker and Wade, 2002).

From global perspective on the overall concepts of knowledge, beliefs and intention to screen for prostate cancer a study findings showed that although older Nigerian men had high rates of general awareness about prostate cancer, their specific knowledge regarding etiology, treatment, prevention, risk perception, and screening were low (Oladimeji et al., 2010). Furthermore, in a recent study among Indian patients Xu et al. (2012) indicated that most men were unaware of treatment options and the outcomes for prostate cancer.

In three Arab countries; Saudi Arabia, Egypt and Jordan, Arafa et al. (2012) explored the knowledge and beliefs of men ages 40 and over towards prostate cancer screening and early detection; the results revealed that men had poor knowledge and fair attitude towards prostate cancer screening behavior, with a Mean total knowledge score of $10.25 \pm 2.5,10.76 \pm 3.39$ and $11.24 \pm 3.39$ and the mean total attitude score of $18.3 \pm 4.08,20.68 \pm 6.4$ and $17.96 \pm 5.3$ in Saudi Arabia, Egypt and Jordan respectively. In a more recent studies were conducted in Jordan, Abuadas (2015), among older Jordanian men showed that most men had low levels of knowledge, beliefs, and intention to screen for prostate cancer. Ahmad et al. (2014) indicated that knowledge gaps and improper practices toward cancer existed among the participants and, if corrected, could improve the care, prevention, and early detection of cancer, this finding was consistent with Ahmad (2015) study findings, which aimed to explore knowledge and beliefs toward cancer in Jordan. Also, (Petro-Nustus and Mikhail, 2002) result showed that having heard or read about cancer found to be significant predictors of screening practice.

When the review focus was narrowed on the intention to screen, Smith-McLallen and Fishbein (2009) observed that African American men who had high levels of perceived behavioral control were more likely to have higher intentions to engage in prostate cancer screening and prostate specific antigen (PSA) test. Whereas, Odedina et al., (2008) indicated attitude was a strong determinant for African-American men to have an intention to screen for prostate cancer. Gregory (2007) showed that $75 \%$ expressed intent to receive PSA screening within a year. Attitude, social influence, and perceived control each contributed significantly to the explanation of intentions, these findings were consistent with (Kenerson, 2010) study. Also, in earlier reviews intrapersonal and interpersonal factors were associated with men receiving prostate cancer screening (Carpenter et al., 2009; Drake et al., 2010)

Intention to screen can serve as bridge that permits the intrapersonal variables to be associated with prostate cancer screening. For example, one study suggested that being married is associated with a higher degree of intention (Blocker et al., 2006; Webb et al., 2006). Such intention, in turn, influenced the likelihood of prostate cancer screening among the more educated men (e.g., better knowledge and resources) as impetus for prostate cancer screening (Drake et al., 2010) and African American men feeling adequately prepared to navigate the health care system in order to have prostate cancer screening (Ross et al., 2007; Arras-Boyd et al., 2009). Thus, a high level of intention is closely associated with a higher likelihood of an individual behaving in a particular way (Ajzen, 2006)

Other studies proved that there was generally poor knowledge and several misconceptions regarding prostate cancer and screening intention, The level of Knowledge, Beliefs, and intention to screen among older adult men are low, which indicate the important to provide health education program to them (McFall et al., 2006; ArrasBoyd et al., 2009; Atulomah et al., 2010; Nakandi et al, 2013; Wanyagah, 2013; Ghodsbin et al., 2014; Abuadas, 2015).

Understanding the perception and knowledge about screening and early detection of cancer is essential to design culturally appropriate and age-appropriate health promotion campaigns and services (Dasoqi et al., 2013).

For the purpose of this systematic review, one may conclude that intention can influence behavior and it is likely that positive intentions can lead to Jordanian men seeking prostate cancer screening, therefore, intention to screen can be a motivating factor for prostate cancer screening of men with low knowledge level and beliefs regarding prostate cancer. Hence, an educational intervention would be prudent and necessary to accomplish this task.

In summary, the previous literature has clearly identified a significance relationship between knowledge and beliefs on intention to screen for prostate cancer. Intention to screen can serve as bridge that permits the intrapersonal variables to be associated with prostate cancer screening and early detecting.

The impact of educational intervention programs on the level of knowledge, beliefs, intention to screen for prostate cancer

On the topic of educational intervention most of the studies were from United States and African-American men. Wilkinson et al. (2003) determined whether a culturally relevant educational program on prostate cancer would enhance knowledge among 835 African-American men and found significant improvements from baseline 
Enhancing Knowledge, Beliefs, and Intention to Screen for Prostate Cancer via Different Health Educational Interventions

as shown in their post-seminar scores assessing prostate cancer knowledge level.

In a quasi-experimental study, Ruthman and Ferrans (2004) tested the effectiveness of a video to teach patients about prostate cancer screening and treatment in a clinical setting and found significant knowledge increase from pretest to posttest among the experimental group and no change in the control group $(\mathrm{p}<0.001)$. Researchers noted that patients in the experimental group changed their preference for PSA screening (31\% experimental vs. $2 \%$ control, $\mathrm{p}=0.002$ ), indicating that patients were influenced by the presented information. Moreover, Taylor et al., (2006) conducted a randomized intervention study on African American men between the ages of 40-70 and determined the effectiveness of two interventions as a printed booklet and a videotape on prostate cancer screening and having conflict with making a decision. The booklet and video significantly improved knowledge and reduced decisional conflict in the experimental group compared to the control group who exhibited a delayed decision making pattern. Frosch et al. (2003) and Taylor et al. (2001) indicated that the preferred forms of educational materials were video and print-based materials and introducing an education program play a significant role to enhance men knowledge and their intent to screen prostate cancer, these results were consistent with others study results (Partin et al., 2004; Capık and Gozum, 2012; Odedina et al., 2014), As well as the conclusion of (Petro-Nustas et al., 2013) Proper education is important in shaping attitudes and beliefs.

To facilitate informed decisions about prostate cancer screening, a randomized controlled trial of three different educational resources for men about prostate cancer screening was conducted by Gattellari and Ward (2005) to 421 men recruited from the Australian community; results showed men in all three groups demonstrated significant increases in knowledge scores from pre to post-test. Men require detailed information about the pros and cons of PSA screening in order to make an informed decision.

Khalil and Abdalrahim (2014) concluded that improvement in population understanding about chronic disease is needed to increase their awareness and practices to make appropriate and effective decisions towards health promotion and better quality of life.

On the same topic, a study conducted in USA, Sheehan (2009) examined the efficacy of a brief digital video intervention on the knowledge and individual risk perceptions for developing prostate cancer among 123 Caucasian men, ages 45-75 years. Men scored significantly higher on a knowledge questionnaire and able to more accurately rate their personal risk after watching the video. Also, a greater number of men showed intention to discuss prostate cancer screening with their primary care provider post-intervention. Moreover, researcher demonstrated an effective and time-efficient educational nursing intervention video for educating men about prostate cancer and prostate cancer screening.

A study by Husaini et al. (2008) assessed the impact of a church based educational program, which included a video, pamphlets, and a question-and-answer session on prostate cancer screening for 430 African American male volunteers (ages 40-70). The findings revealed that a lowcost prostate cancer awareness campaign within a church may be enough to affect prostate cancer knowledge, beliefs, and behaviors among African American men.

A recent study, Ukoli et al. (2013) observed the impact of tailored prostate cancer education on knowledge and screening among 539 low-income African Americans men and found that 15-minutes education interventions (providing a prostate cancer brochure and tailored interaction) led to improved knowledge, beliefs, and action. Furthermore, researchers showed that a balanced educational intervention on the risks and benefits of prostate cancer screening helped provide a platform for participants to make informed decisions and dramatically increased PSA testing, among men who did not have access to regular physical examinations.

In conclusion, educational intervention programs were found in literature to increase perceptions, knowledge, beliefs and intent to screen prostate cancer which has a direct effect on improving healthcare outcomes.

Information Gaps in Literature: Systematic review and analysis of selected research literatures showed that majority of researchers were interested in the knowledge, beliefs, and intention to screen for prostate cancer and their results unanimously supported the use of an effective and dynamic educational intervention as a fundamental requisite for prevention and early detection of prostate cancer. Also, we found congruence and no contrast in literature among the researchers using quasi-experimental design, and in four studies of a qualitative approach. Therefore, unavailable qualitative research may limit the richness of details.

Further studies using different designs to implement educational programs could perhaps identify the needs and priorities of the target population. According to published studies (Arafa et al., 2012; Abuadas, 2015), In Jordan, adult males have low knowledge levels, beliefs, and intention to screen for prostate cancer. Thus, we recommend focusing on educational interventions to enhance knowledge, beliefs, and intention to screen for prostate cancer among the Jordanian men.

Relevance to Clinical Practice: Enhanced knowledge, beliefs, and intention to screen for prostate cancer through different educational materials is an important clinical practice issue. There is a need for targeted educational materials, particularly materials that are balanced in terms of risks and benefits of early screening. Improved knowledge would produce corresponding improvement in screening, knowledge and beliefs to serve as an important preventive approach for life threatening health issues such as prostate cancer. Literature supports that educated and informed men, seek screening for early detection of prostate cancer.

Future Directions and Recommendations:The studies finding support that the use of constant, persistent, and dynamic educational activities are a fundamental requisite for the prevention and early detection of prostate cancer. Although there is no empirical evidence as of yet that prostate cancer screening reduces mortality, screening may be beneficial for men at increased risk for prostate cancer, such as African American men (Harris et al., 2004). 
Furthermore, a church-based intervention delivered by a health educator is a promising strategy for promoting knowledge and beliefs among men (Drake et al., 2010). Therefore, More rigorous study designs (e.g. longitudinal studies, RCT's) are needed to further test this intervention strategy. More research is needed to examine the extent to which gaining knowledge and beliefs improve intention to screen for better outcomes. Assessment of psychosocial factors among different ethnic groups may facilitate the decision making processes (e.g., spiritual or religious beliefs). In addition, developing an assessment strategy based on the health belief model (HBM) seems appropriate for designing and effectively implementing an educational program for men in Jordan.

Limitation: In this systematic review of literature, we found four qualitative research design, which may limit the richness of details on knowledge, beliefs and intention to screen for prostate cancer.

Conclusions: We conclude that in order to stimulate regular screening among men, healthcare providers and researchers should design an effective health promotion plan and educational intervention program to increase awareness and to correct false impressions about prostate cancer in Jordan. The needs assessment of communities based on the health belief model (HBM) could be the first effective approach to design and implement an educational program for any target population. Educational programs should be designed so that public misperceptions are identified and corrected, in order for the individuals recognize health concerns and gain more knowledge. Furthermore, we found that educational video are significantly effective educate and motivate participants about the benefits of PSA screening for early detection of prostate cancer.

\section{References}

Abuadas M (2015). Jordanian men's health beliefs, intentions, and behaviors regarding prostate cancer screening. doctoral dissertation, The University of Jordan, Jordan.

Al Dasoqi K, Zeilani R, Abdalrahim M, Evans C (2013). Screening for breast cancer among young Jordanian women: ambiguity and apprehension. Int Nurs Rev, 60, 351-7

Ahmad, MM (2015). Knowledge and beliefs about Cancer Prevention and Care in Jordan. Int J Med, 1, 1-5.

Ahmad MM, Dardas LA, Ahmad H (2014). Cancer prevention and care: A national sample from Jordan. J Cancer Educ, 30, 301-11.

Ahmad MM, Musil CM, Zuaszniewski JA, Resnick MI (2005). Prostate cancer: appraisal, coping, and health status. $J$ Gerontol Nurs, 31, 34-43.

Agho AO Lewis MA (2001). Correlates of actual and perceived knowledge of prostate cancer among African Americans. Cancer Nurs, 24, 165-71.

Ajape AA, Babata A, Abiola OO (2010). Knowledge of prostate cancer screening among native African urban population in Nigeria. Public Health, 20, 94-6.

Ajzen I (2006) Diagram for the theory for planned behavior. Retrieved February 4, 2006. From http://people.umass.edu/ aizen/tpb.diag.html

Anderson MM (2013). Testing the health belief model using prostate cancer screening intention: comparing four statistical approaches applied to data from the 2008-
09 nashville men's preventive health survey (doctoral dissertation, vanderbilt university).

Arafa MA, Rabah DM, Wahdan IH (2012). Awareness of general public towards cancer prostate and screening practice in Arabic communities: a comparative multi-center study. Asian Pacific J Cancer Prev, 13, 4321-6.

Arras-Boyd RE, Boyd RE, Gaehle K (2009). Reaching men at highest risk for undetected prostate cancer. Int J Men's Health, 8, 116-28.

Atulomah NO, Olanrewaju MF, Amosu AM, Adedeji O (2010). Level of awareness, perception and screening behavior regarding prostate cancer among men in a rural community of ikenne local government Area, Nigeria. Primary Prev Insights, 2, 11-20.

Blocker DE, Romocki LS, Thomas KB, et al (2006). Knowledge, beliefs and barriers associated with prostate cancer prevention and screening behaviors among AfricanAmerican men. J National Med Assoc, 98, 1286-95.

Breen N, Wagener DK, Brown ML, Davis WW, Ballard-Barbash R (2001). Progress in cancer screening over a decade: results of cancer screening from the 1987, 1992, and 1998 national health interview surveys. J National Cancer Inst, 93, 1704-13.

Capık C, Gozum S (2012). The effect of web-assisted education and reminders on health belief, level of knowledge and early diagnosis behaviors regarding prostate cancer screening. Eur J Oncol Nurs, 16, 71-7.

Carpenter WR, Godley PA, Clark JA, et al (2009). Racial differences in trust and regular source of patient care and the implications for prostate cancer screening use. Cancer, 115, 5048-59.

Chapple A, Ziebland S, Hewitson P, McPherson A (2008). Why men in the United Kingdom still want the prostate specific antigen test. Qual Health Res, 18, 56-64.

Clarke-Tasker VA, Wade R (2002). What we thought we knew: African American males' perceptions of prostate cancer and screening methods. ABNF $J, \mathbf{1 3}, 56-60$.

Drake BF, Shelton R, Gilligan T, Allen JD (2010). A churchbased intervention to promote informed decision-making for prostate cancer screening among African-American men. $J$ National Med Assoc, 102, 164-71.

Edwards QT, Johnson CG, Mason S, Boyle G (2000). Differentiation of the health behavior patterns related to prostate cancer screening among African-American men in military settings. Mil Med, 167, 374-8.

Ferlay J, Soerjomataram I, Ervik M, et al (2013). GLOBOCAN 2012 v1. 0. Cancer incidence and mortality worldwide: IARC Cancer Base, 11. 2013.

Forrester-Anderson IT (2005). Prostate screening perceptions, knowledge, and behaviors among African American men: focus group findings. $J$ Health Care Poor Underserved, 16, 22-30.

Frosch DL, Kaplan RM, Felitti VJ (2003). A randomized controlled trial comparing internet and video to facilitate patient education for men considering the prostate specific antigen test. J General Internal Med, 18, 781-7.

Gattellari M, Ward, JE (2005). A community-based randomised controlled trial of three different educational resources for men about prostate cancer screening. Patient Educat Counsel, 57, 168-82.

Ghodsbin F, Zare M, Jahanbin I, Ariafar A, Keshavarzi S (2014). A survey of the knowledge and beliefs of retired men about prostate cancer screening based on health belief model. International J Community Based Nurs And Midwifery, 2, 279-85.

Gregory DJ (2007). Iowa men's decision-making process for prostate cancer prevention via screening with the prostate- 
Enhancing Knowledge, Beliefs, and Intention to Screen for Prostate Cancer via Different Health Educational Interventions specific antigen (PSA) test. Theses Dissertat, 177.

Harris TM, Parrott R, Dorgan KA (2004). Talking about human genetics within religious frameworks. Health Communicat, 16, 105-16.

Husaini BA, Reece MC, Emerson JS, et al (2008). A Churchbased program on prostate cancer screening for African American men: reducing health disparities. Mortality, 18, 179-184.

Jemal A, Siegal R, Ward E, et al (2007). Cancer statistics, 2007. CA Cancer J Clin, 57, 43-66.

Kenerson D (2010). Use of the theory of planned behavior to assess prostate cancer screening intent among African American men (doctoral dissertation, vanderbilt university).

Khalil A, Abdalrahim M (2014). Knowledge, attitudes, and practices towards prevention and early detection of chronic kidney disease. Int Nurs Rev, 61, 237-45.

Kroger-Jarvis M (2014). Evaluating prostate cancer knowledge in Rural Southeastern Indiana County. Online Journal of Rural Nursing and Health Care, 14, 83-99.

Lozano R, Naghavi M, Foreman K, et al (2012). Global and regional mortality from 235 causes of death for 20 age groups in 1990 and 2010: a systematic analysis for the global burden of disease study 2010. Lancet, 380, 2095-128.

McFall SL, Hamm RM, Volk RJ (2006). Exploring beliefs about prostate cancer and early detection in men and women of three ethnic groups. Patient Educat Counsel, 61, 109-16.

Mofolo N, Betshu O, Kenna O, et al (2015). Knowledge of prostate cancer among males attending a urology clinic, a South African study. Springer Plus, 4, 67-73.

Moore AD, Boyle G (2002). Assessing the knowledge, selfefficacy and health behaviors of male beneficiaries assigned to the national capital area regarding participation in prostate screening. uniformed services univ of the health sciences bethesda md.

Myers RE, Hyslop T, Jennings-Dozier K, et al (2000). Intention to be tested for prostate cancer risk among African-American men. Cancer Epidemiol Biomarkers Prev, 9, 1323-8.

Nakandi H, Kirabo M, Semugabo C, et al (2013). Knowledge, attitudes and practices of Ugandan men regarding prostate cancer. African J Urol, 19, 165-70.

National Cancer Institute, (2015a). Prostate Cancer. Retrieved May 29, 2015, from http://www.cancer.gov/types/prostate

National Cancer Institute, (2015b). Prostate Cancer Treatment. Retrieved May 29, 2015, from http://www.cancer.gov/ types/prostate

Nivens AS, Herman J, Pweinrich S, Weinrich MC (2001). Cues to participation in prostate cancer screening: a theory for practice. Oncol Nurs Forum, 28, 1449-56.

Odedina FT, Campbell ES, LaRose-Pierre M, Scrivens J, Hill A (2008). Personal factors affecting African-American men's prostate cancer screening behavior. J National Med Associat, 100, 724-33.

Odedina FT, Oluwayemisi AO, Pressey S, et al (2014). Development and assessment of an evidence-based prostate cancer intervention Programme for black men: the WORD on prostate cancer video. Ecancermedicalscience, 8, 260-75.

Oladimeji O, Bidemi YO, Olufisayo JA, Sola AO (2010). Prostate cancer awareness, knowledge, and screening practices among older men in Oyo State, Nigeria. Int Quarterly Community Health Educat, 30, 271-86.

Paiva EPD, Motta MCSD, Griep RH (2010). Knowledge, attitudes and practices regarding the detection of prostate cancer. Acta Paulista de Enfermagem, 23, 88-93.

Partin MR, Nelson D, Radosevich D, et al (2004). Randomized trial examining the effect of two prostate cancer screening educational interventions on patient knowledge, preferences, and behaviors. J General Internal Med, 19, 835-42.

Paul C, Tzelepis F, Walsh RA, et al (2003). Has the investment in public cancer education delivered observable changes in knowledge over the past 10 years? Cancer, 97, 2931-39.

Petro-Nustus W, Mikhail BI (2002). Factors associated with breast self-examination among jordanian women. Public Health Nurs, 19, 263-71.

Petro-Nustas W, Tsangari H, Phellas C, Constantinou C (2013). Health beliefs and practice of breast self-examination among young Cypriot women. J Transcultural Nurs, 24, 180-8.

Ruddon RW (2007). Cancer biology. In "The Biochemistry and Cell Biology of Cancer", Oxford University Press, 117-20.

Ruthman JL, Ferrans CE (2004). Efficacy of a video for teaching patients about prostate cancer screening and treatment. American J Health Promot, 18, 292-5.

Schulman CC, Kirby R, Fitzpatrick JM (2003). Awareness of prostate cancer among the general public: Findings of an independent international survey. European Urology, 44, 294-302.

Sheehan CA, (2009). A Brief educational video about prostate cancer screening: a community intervention. Urologic Nurs, 29, 103-17

Smith-McLallen A, Fishbein M (2009). Predicting intentions to engage in cancer prevention and detection behaviors: Examining differences between Black and White adults. Psychol Health Med, 14, 180-9.

Stewart BW, Wild CP (2014). World cancer report 2014. lyon, france: international agency for research on cancer.

Tarawneh M, Nimri O, Arkoob K, Zaghal MA (2010). Cancer incidence in jordan 2010. non-communicable diseases directorate, jordan cancer registry. ministry of health.

Taylor KL, Davis JL, Turner RO, et al (2006). Educating African American men about the prostate cancer screening dilemma: a randomized intervention. Cancer Epidemiol Biomarkers Prev, 15, 2179-88.

Taylor KL, Turner RO, Davis JL, et al (2001). Improving knowledge of the prostate cancer screening dilemma among African American men: an academic-community partnership in Washington, DC. Public Health Reports, 116, 590-8.

Ukoli FA, Patel K, Hargreaves M, et al (2013). A tailored prostate cancer education intervention for low-income African Americans: Impact on knowledge and screening. Journal of health care for the poor and underserved, 24, 311-31.

U.S. Cancer Statistics Working Group. (2009). United States cancer statistics: 1999-2005 incidence and mortality webbased report. Retrieved September 21, 2009, from Available at: http://www.cdc.gov/uscs .

Wanyagah P (2014). Prostate cancer awareness, knowledge, perception on self-vulnerability and uptake of screening among men in nairobi county, kenya (doctoral dissertation).

Webb CR, Kronheim L, Williams JE, Hartman TJ (2006). An evaluation of the knowledge, attitudes, and beliefs of African-American men and their female significant others regarding prostate cancer screening. Ethnicity and Disease, 16, 234-8.

Weinrich S, Vijayakumar S, Powell IJ, et al (2007). Knowledge of hereditary prostate cancer among high risk African American men. Oncol Nurs Forum, 34, 854- 60.

Wilkinson S, List M, Sinner M, Dai L, Chodak G (2003). Educating African-American men about prostate cancer: impact on awareness and knowledge. Urol, 61, 308-13.

Xu J, Neale AV, Dailey RK, Eggly S, Schwartz KL (2012). Patient perspective on watchful waiting/active surveillance for localized prostate cancer. J Am Board Family Med, 25, 763-70. 